\title{
How to Succeed? An Analysis of the Impact of Women Founder's Personality Traits on Chinese Apparel New Venture Success
}

\author{
Li Zhao and Jung Ha-Brookshire, University of Missouri, USA
}

Keywords: New Ventures, Women Founder, Success, Personality Traits

According to Global Entrepreneurship Monitor (GEM) report, nearly 126 million women were starting or running new businesses in 67 economies around the world at the time the survey was conducted (GEM, 2012). In China, women's entrepreneurship has also become a new trend in recent years. Women enter into new ventures to enrich their lives with careers as well as to attain financial independence $(\mathrm{Hu}, 2007)$. However, it is shown that women's involvement of total entrepreneurial activity rate is $11 \%$, compared to $15 \%$ for men in China. Some studies have revealed that women have different characteristics in entrepreneurial activities compared to men, especially personality traits $(\mathrm{Hu}, 2007)$. This has yet to be empirically tested in Chinese apparel new ventures. Because most women-founded businesses are in the consumer sector, such as the service industry or retailing, and fashion, it is important to identify the role of personality traits towards business success among this demographic segment of society.

According to Barney's (1991) resource-based view of the firm, a competitive firm is configured by unique, rare, valuable, and costly-to-copy sets of resources and capabilities. One research stream about new venture performance focuses on founders' big five personality traits. That is, if a founder has a certain personality, the new venture may have a greater competitive advantage. Founders' personality traits can be treated as a key resource related to structure, strategy, and new venture performance. Female founders are associated with high need for independence, personal development, self-rule, innovativeness, risk-taking, proactive, and competitive aggressiveness (Morrison, 2000). These characteristics can be grouped into the big five factor personality traits framework includes extraversion, openness to experience, agreeableness, conscientiousness, and emotional stability (Barrick \& Mount, 1991). Yet, which personality trait has a greater impact on women-owned new venture performance is not known.

To fill this gap, a quantitative research method was used in this study. An online survey was administrated as it is useful to target specific populations and at a time and place of the participants' convenience (Victor, 2006). Due to the difficult-to-reach population of the sample subjects and lacking an adequate sampling frame, the purposive sampling technique was used (Victor, 2006). Female founders of Chinese apparel new ventures were selected as the target sampling group of this study. Goldberg (1999)'s 50-item IPIP inventory was used, and from Ling-yee and Ogunmokun (2001), new venture success was measured by profitability, sales volume, market share, and productivity. Data were collected from February 2015 to March 2015. 130 usable responses were used for further data analysis. Sample demographics indicated that most of the female founders who participated in the study were below 40 years of age.

Page 1 of 2 
Additionally, $90 \%$ of the participants completed college education. All study variables had Cronbach's Alpha of 7 or above.

The key statistics of the personality traits of the study respondents showed that they have high levels of agreeableness ( $\mu$ 4.11; Sd .45), conscientiousness ( $\mu$ 4.05; Sd .52), and openness to experience ( $\mu$ 3.89; $\mathrm{Sd} .5)$. Correlation analysis and multiple regression analyses were done to determine whether these traits had a relationship with new venture success. There was a strong positive relationship between all five personality traits and new venture performance: conscientiousness ( $\mathrm{r}=.271, p<.01)$, agreeableness $(\mathrm{r}=.297, p<.01)$, openness to experience $(\mathrm{r}=.249, p<.01)$, emotional stability $(\mathrm{r}=.302, p<.01)$, extraversion $(\mathrm{r}=.242, p<.01)$. However, multiple regression analysis showed that emotional stability is the only statistically significant predictor of new venture performance $(\beta=.174 ; p<.1)$ with adjusted $R$-square of $9.2 \%$. That is, women founders with higher levels of emotional stability and fewer persistent negative feelings may be more likely to succeed as entrepreneurs.

This research offers important implications and contributions. First, a resource-based theory of the firm was shown as a useful theoretical framework to analyze female founders' personality traits. Among the big five traits, emotional stability is important for women entrepreneurs' success. Therefore, local governments and academic organizations could utilize this finding to make appropriate policies, training programs, and community supports to help women-owned apparel new ventures. Future investigation may be necessary to understand the differences between female and male founders' personality traits and their impact on new apparel venture success in China.

\section{References:}

Hu, HM. (2007). Research on Female Entrepreneurship and Influential Factors in China. Doctoral Dissertation.

Xavier, S., Kelley, D., Kew, J., Herrington, M., \& Vorderwülbecke, A. (2013). Global Entrepreneurship Monitor (GEM) 2012 Global Report. GERA/GEM.

Barney, J. (1991). Firm resources and sustained competitive advantage. Journal of management, 17(1): $99-120$.

Jupp, V. (2006). The Sage dictionary of social research methods. Sage.

Morrison, A. (2006). A contextualisation of entrepreneurship. International Journal of Entrepreneurial Behavior \& Research, 12(4), 192-209.

Barrick, M. R., \& Mount, M. K. (1991). The big five personality dimensions and job performance: a meta-analysis. Personnel psychology, 44(1), 1-26.

Goldberg, L. R. (1999). International Personality Item Pool: A scientific collaboratory for the development of advanced measures of personality and other individual differences. Retrieved August, 14, 2002.

Ling-yee, L., \& Ogunmokun, G. O. (2001). The influence of interfirm relational capabilities on export advantage and performance: an empirical analysis.International Business Review, 10(4), 399-420.

Page 2 of 2

( $)$ 2015, International Textile and Apparel Association, Inc. ALL RIGHTS RESERVED

ITAA Proceedings, \#72 - www.itaaonline.org 